\title{
Ethical perspectives on combating sex trafficking in Nepal
}

\author{
Anupa Rijal \\ Tara Ballav Adhikari \\ Arja R Aro \\ Unit for Health Promotion Research, \\ Faculty of Health Sciences, University \\ of Southern Denmark, Esbjerg, \\ Denmark
}

This article was published in the following Dove Press journal:

Medicolegal and Bioethics

16 August 2016

Number of times this article has been viewed
Correspondence: Anupa Rijal Unit for Health Promotion Research, Faculty of Health Sciences, University of Southern Denmark, Niels Bohrs Vej 9-10, 6700 Esbjerg, Denmark Email anuparijal@gmail.com
Abstract: Sex trafficking, where individuals are traded for sex purposes and abused sexually, physically, mentally, and economically leading to repercussions in individual liberty, social life, and health and well-being, is one of the worst forms of infringement of human rights. Despite the growing global concern against sex trafficking, thousands of individuals, mostly girls and women, are trafficked annually, especially from low- and middle-income countries like Nepal. This article discusses the public health issues related to sex trafficking and the different ethical approaches - libertarianism, paternalism, stewardship, and virtue ethics - on perspectives concerning combating sex trafficking in Nepal. Along with the legal standpoint, awareness-raising activities, transit monitoring, and limited rehabilitative programs, Nepal also needs to enhance its stewardship approaches by addressing the gender-sensitive nature of the problem through empowerment and livelihood programs for girls and women from vulnerable communities to combat sex trafficking effectively.

Keywords: women, exploitation, public health, libertarianism, paternalism, stewardship, Nepal

\section{Introduction}

According to the Universal Declaration of Human Rights, every individual is entitled to enjoy life, liberty, and a sense of security; slavery, servitude, and the slave trade are prohibited in any form. ${ }^{1}$ Six decades after the declaration came into force, the world is still in the grasp of one of the worst acts of infringement of human rights: sex trafficking, a modern-day form of slavery. ${ }^{2}$

Sex trafficking means the recruitment, transportation, transfer, and receipt of persons by means of violence, lies, threats, debt bondage, deception, abuse of power, or vulnerability of a person, or other forms of coercion that compel individuals to engage in commercial sex or other forms of sexual exploitation against their will. Sexual exploitation involving a child below 18 years is considered trafficking, regardless of the means. ${ }^{3}$ Sex trafficking is one of the most common $(79 \%)$ and visible forms of human trafficking prevalent in our society. ${ }^{4}$ It is present in different forms and is evident throughout the world. ${ }^{4,5}$ Human trafficking has grown up as a lucrative and illicit form of organized transnational crime and business creating enormous economies estimated at $\$ 32$ billion annually for the trafficking agents. ${ }^{6-8}$

Annually, around 800,000 people are trafficked across international borders; $80 \%$ are female and half of them are minors. ${ }^{7}$ The actual burden of the growing pandemic of sex trafficking is still unaccounted for owing to lack of evidence. ${ }^{4,8}$ Human trafficking is evidently common in poor countries, including South Asian countries such as Nepal, 
Bangladesh, and India, and predominantly involves girls. ${ }^{4}$ The majority of girls and women from Nepal, Bangladesh, and within different states of India are trafficked to brothels of major Indian cities and forced into prostitution, pornography, and strip shows, or are involved in sex tourism, while the rest are trafficked across international borders. Yearly, 5,000-7,000 Nepali girls are trafficked; 100,000-200,000 are currently in brothels in India and a quarter of them are below 18 years. ${ }^{9}$ Approximately 74\% of the trafficked girls are unmarried and $70 \%$ of them are $14-18$ years of age. ${ }^{10}$

In recent years, Nepali girls and women have fallen victim to being trafficked to the Gulf countries such as Saudi Arabia and the UAE; they are employed or promised employment as domestic workers. ${ }^{11}$ Moreover, girls are also trafficked to work in massage parlors, spas, dance bars, and restaurants where sexual exploitation is very common. ${ }^{9,11,12}$

Various factors lead to sex trafficking in Nepal that is born out of the complex chain of poverty, gender disparity in the society, and lack of educational and economic opportunities for women and girls, blended with a poor legal and judicial system, increased impunity, and lack of political willingness to prioritize the issue. ${ }^{11,12}$

Sex trafficking breaches every aspect of human rights and ethical principles. A girl who is trafficked for sex is devoid of her fundamental rights to have a dignified, safe, and secure life. She loses autonomy over her body, right to make life choices, and sexual and reproductive choices, and the right to earn a healthy and respected living. Despite the national and international realization of the gravity of the problem, very little has been achieved in combating sex trafficking; further, the ethical implications of trafficking are often ignored.

This paper focuses on the scenario of sex trafficking in Nepal and the public health issues related to it, and presents a discourse of ethical approaches that come into play while combating sex trafficking.

\section{Sex trafficking and public health issues at stake in Nepal}

Sex trafficking has public health implications and presents a range of ethical challenges in combating it at the individual, community, national, and global levels. Health problems, violence against women, lack of evidence, and poor implementation of legal provisions against sex trafficking are some of the major public health issues at stake in Nepal.

The consequences of sex trafficking bring about different health hazards in different forms and at different stages of being trafficked. ${ }^{6}$ Unsafe sexual activities in compromised environments increase the chances of acquiring sexually transmitted diseases, including human immunodeficiency virus/acquired immunodeficiency syndrome, vaginal tearing, unwanted pregnancies, and miscarriages. Victims are prone to suffer from physical violence resulting in mild to severe disabilities, and sometimes even in death. ${ }^{6,7}$ Mental disorders such as anxiety, depression, and post-traumatic stress disorders are significantly higher among girls who have been trafficked for sex than the trafficked but non-sex working group. ${ }^{13}$ Furthermore, social isolation, stigmatization, and poor livelihoods even after being rescued pose prominent social and mental health problems. ${ }^{6,7}$

The health problems of children and adolescent girls take an even more serious turn if trafficked. ${ }^{14}$ As these young people are often economically violated, they have poor access to health care, which further exacerbates their health problems. ${ }^{5}$ Children born from these trafficked women are also more likely to be victims of child abuse/violence and forced to join commercial sex business; thus, an intergenerational vicious cycle of violence, poverty, and exploitation is created.

There is no uniform evidence of the number of girls and women trafficked; the government and each organization has its own numbers. This lack of data creates an obstacle to develop and implement evidence-based antitrafficking programs in Nepal. ${ }^{15}$

\section{Ethical approaches to combat sex trafficking}

When it comes to decision making in public health, there are no definite ethical frameworks that address the complex legal, social, and individual perspectives of public health problems. ${ }^{16}$ The aim of public health is primarily to achieve community health without compromising the individual rights of persons living in the community, along with respect for the community's diverse values, beliefs, and cultures. ${ }^{17}$ Hence, any decision taken at the policy level or during design of the intervention or in its implementation should comply with the ethical principles of "do good", "do no harm", "equity", "respect", “empowerment", "sustainability", "social responsibility", "participation", "openness", and "accountability". ${ }^{18}$ However, not all of these ethical principles can be addressed through a single approach. So, in the sensitive issue of combating sex trafficking, ethical dilemmas are even more pertinent. Hence, we discuss the different ethical approaches, namely, libertarianism, paternalism, stewardship, and virtue ethics, regarding what ethical principles they hold and what other ethical principles they breach, with debate on whether the approaches are sufficient to guide practice or policymaking to combat sex trafficking in Nepal. 


\section{Libertarianism approach to combat sex trafficking}

The libertarian approach holds that the state's legitimate activity is to establish a political institution that provides a doctrine of individual rights and a judicial body to protect these rights from being violated through appropriate punishment. ${ }^{19}$ Apart from this, it believes that any intrusion from the state is outside of its scope. ${ }^{19}$ With respect to the libertarian approach in Nepal, the constitution of the country promulgates gender equality and condemns any act of trafficking. Nepal is also a signatory to eleven different conventions on women's rights and health, including the Convention on Elimination of all forms of Discrimination Against Women and the Beijing Declaration. ${ }^{11}$ The new Human Trafficking Control Act is in effect since 2007 in the country. ${ }^{4}$ The act also prescribes legal provision of imprisonment along with fines, and compensation for the victims of human trafficking. ${ }^{20}$

Another characteristic of the libertarian approach is its focus on rights. A rights-based approach in the case of sex trafficking is based on international human rights standards, operational guidelines, conventions, treaties, policies, and laws that treat individuals as ends in themselves and provide the environment to make one's own decisions. ${ }^{16}$ Yet, is a rights-based approach sufficient to address antitrafficking? The main problem is that many states often fail to safeguard the rights of individuals and have a poor commitment to implement the laws regulating those rights. ${ }^{21}$ This leads to discriminatory practices and unjust power distribution that again create conditions of impunity for traffickers and denial of justice for victims. ${ }^{10,22}$ Similar implementation challenges prevail in the case of Nepal as well. ${ }^{22}$

In the case of sex trafficking, simply ensuring that one is entitled to rights and will be punished if harm is done does not address a problem that is multifaceted in nature. Many people are simply not aware of their rights, and the law against such crimes is poorly understood. Only $66 \%$ of adolescent girls from one of the most vulnerable areas in Nepal were aware of sex trafficking, and $48.3 \%$ had negative attitudes toward victims and/or antitrafficking campaigns. ${ }^{23}$ Traffickers easily lure girls and women by promising good jobs, better lives, and sometimes even marriage, ${ }^{2,9}$ this further diminishes their apparent freedom to judge the situation and act effectively. Legalizing prostitution may end some forms of violence associated with sex trafficking. However, legalizing something that many consider unethical activity is also heavily criticized. ${ }^{24}$ Sex trafficking will continue to thrive until effective rights against gender-based violence and the rights to education and health come into play. ${ }^{25}$

\section{Paternalistic approach to combat sex trafficking}

The paternalistic approach in ethics means that interference of the state in the liberty of persons against their will is justified by the claim that the target person of interference will be better off or protected from harm. ${ }^{19,21}$ This approach provides a sense of doing good, accountability, and social responsibility; however, it limits individual freedom and respect.

One of the successful paternalistic approaches in Nepal in preventing sex trafficking is transit monitoring. Girls and women are trafficked across the free border between Nepal and India. Scrutinizing the movements of individuals while crossing the border is shown to be successful in preventing girls from being transited illegally. ${ }^{15}$ According to Maiti Nepal, 134,718 migrants were informed about possible trafficking events at borders, 183 victims were rescued, and 2,904 were intercepted in 2014 alone. ${ }^{26}$ In 2012, the Government of Nepal further applied a nudging strategy by introducing a ban on women below the age of 30 traveling to Gulf countries for domestic work; but owing to the corrupted official system in Nepal, the intervention was not successful. ${ }^{15}$

One may argue that such an action infringes on the liberty of individuals, but its counterargument supported by "Mills' harm principle" better weighs up the argument: power exercised can be justified over any member of the civilized society if it is to prevent harm to others. ${ }^{21}$ Evidence suggests that such monitoring has helped to track the traffickers and prevents many girls from being trafficked. ${ }^{15}$ However, it is important to guarantee that such restrictions are nondiscriminatory, supported by law, consistent with other rights, and used only when strictly necessary. ${ }^{27}$

Antitrafficking programs in Nepal can be divided into prevention programs, indirect prevention, remediation, and advocacy. ${ }^{28}$ The activities of many (international) nongovernmental organizations working in the most vulnerable places in Nepal are inconsistent with government activities that are often inactive, rampant, superficial, and lack clear reporting and evaluation of programs. ${ }^{12}$ This shows that when the government fails in its role as guardian, the disaggregated efforts to combat sex trafficking have little impact.

Creating comprehensive awareness about understanding sex trafficking is yet another paternalistic aspect of preventing trafficking. However, one should be highly cautious as there is evidence that parents even take their girls out of school to limit their interaction with strangers, because of incompetent nudging. Many of the awareness programs in the affected region dictate the do's/don'ts, rather than supporting informed 
decisions to make the enlightened choices that would prevent sex trafficking. ${ }^{12}$

\section{Stewardship approach to combat sex trafficking}

In the stewardship approach, the concerned authorities are obliged to look after the needs at the community and individual levels by addressing the inequities and vulnerabilities generated by age, gender, ethnic background, socioeconomic status, social constructs, and lack of opportunities. ${ }^{19}$ Hence, addressing sex trafficking through the stewardship approach would include rescue, repatriation, appropriate rehabilitation, and creating an environment for reintegration of victims with special consideration for girls and women from vulnerable communities. ${ }^{10}$

In the case of the rehabilitation of a trafficked victim, the "communitarianism" concept can argue that bringing a trafficked person back into the community will increase transmission of diseases like human immunodeficiency virus/ acquired immunodeficiency syndrome (HIV/AIDS) and may lead to an increase in trafficking activity in the community. So, for the greater good of protecting other members of the community, the trafficked person should not be reintegrated back into the society. Meanwhile, such an obstruction is also a direct attack on the autonomy of the individual and is firmly backed by libertarianism. However, poor subsistence, social isolation from family or community, stigmatization, poor reintegration to social life before being trafficked, and vulnerability to intimidation increase the chances of being trafficked again or returning to their previous exploiters. ${ }^{6,7}$ Victims are also very much less likely to make rational decisions even if they are provided with right choices. Thus, it is important to build violence-free care or training centers before returnees are rehabilitated into the community to ensure that they receive the required health care services, social and legal support, and livelihood training. In the Nepalese context, in particular, this would enable the returnees to have an economically and socially secured lifestyle. ${ }^{10,27}$

In order to formulate interventions acknowledging ethical principles and approaches, evidence is of utmost importance. ${ }^{18}$ The stewardship approach supports research to identify trafficked victims and their needs, and appropriate interventions to combat sex trafficking. In addition, research should prevent revictimization, by maintaining the confidentiality and security of survivors. These "survivors" can be role models and actors in preventing trafficking in the future; that is why, their anonymity should be maintained and informed consent must be obtained during the research. ${ }^{29,30}$ Effective negotiations to identify and break the chain of sex trafficking between the Government of Nepal and the destination country can be one of the long-term stewardship responses to the problem.

Hence, in the case of combating sex trafficking, this approach can be justified as a comprehensive one as it upholds many ethical principles of empowerment, equity, accountability, respect, openness, and participation.

\section{Virtue ethics to combat sex trafficking}

One may argue that a solution to sex trafficking is not possible until and unless the related stakeholders, be it a nation, citizens, or individuals throughout the world accept that sex trafficking is an offensive exploitation of human rights. Virtue ethics focuses on the characteristics of agents rather than on action; it provides the alternative to the narrower principles discussed earlier. However, it is a long-term process and will not be effective to lessen the burden of sex trafficking immediately; nonetheless, the installation of virtuous behavior and suppression of vice is of enormous importance. ${ }^{31}$

\section{Conclusion}

In this globalized era, sex trafficking is still a social and public health problem in Nepal. It questions the very existence of humanity and poses critical ethical questions on the legal and social regulations of the nation. It is evident that combating sex trafficking requires the combined efforts of public health, social, legal, and political networks throughout the world. The rights-based approach of "libertarianism", awareness raising, transit monitoring, nudging of paternalism and reducing vulnerability through effective policy and interventions, and appropriate research in stewardship approaches have been successful in minimizing sex trafficking; however, they are very subjective and individualistic measures.

Considering these ethical approaches, it is clear that there is no single solution to this multifaceted problem of sex trafficking. Nepal needs to collaborate with related stakeholders at the community, national, and international levels, and especially with India, with which Nepal shares an open border and to where the majority of girls are being trafficked. Empowering vulnerable communities, especially girls and women, to fight deep-rooted poverty and gender disparity through life skill-based educational and vocational opportunities is a must. Lack of uniform evidence points to the need for scientific research and appropriate reporting mechanisms to address the issue. Finally, there should be effective community involvement along with multilateral 
networks supported by legal jurisdiction to prevent trafficking and rescue victims, followed by appropriate physical, social, economic, and rehabilitation efforts for trafficked girls and women.

\section{Disclosure}

The authors report no conflicts of interest in this work.

\section{References}

1. UN. The Universal Declaration of Human Rights. New York: United Nations; 1948.

2. Office on Trafficking in Persons (US). Fact sheet: sex trafficking (English) Wahington, DC, US: U.S. Department of Health and Human Services; 2012 [updated December 3, 2015; cited December 29, 2015]. Available from: http://www.acf.hhs.gov/programs/endtrafficking/resource/factsheet-sex-trafficking-english. Accessed December 27, 2015.

3. UN. Protocol to Prevent, Suppress and Punish Trafficking in Persons, Especially Women and Children, Supplementing the United Nations Convention Against Against Transnational Crime. New York: United Nations General Assembly; 2000.

4. UN Global initiative to fight human trafficking. Global Report on Trafficking in Persons. United Nations Office on Drugs and Crime; 2009.

5. Macias Konstantopoulos W, Ahn R, Alpert EJ, et al. An international comparative public health analysis of sex trafficking of women and girls in eight cities: achieving a more effective health sector response. J Urban Health. 2013;90(6):1194-1204.

6. World Health Organization. Understanding and Addressing Violence Against Women. Intimate partner violence; 2012.

7. Deshpande NA, Nour NM. Sex trafficking of women and girls. Rev Obstet Gynecol. 2013;6(1):e22-e27.

8. Factsheet on Human Trafficking. United Nations Office on Drugs and Crime; 2010

9. Bank AD. Combating Trafficking of Women and Children in South Asia: Regional Synthesis Paper for Bangladesh, India, and Nepal. Asian Development Bank; 2003.

10. Upadhyay P, Koirala G, Singh S, et al. Best Practices on Rehabilitation and Reintegration of Trafficked Women and Girls. Kathmandu: SAHARA Group and Beyond Trafficking: Joint Initiative in the Millenium against Trafficking in Girls and Women (JIT-NEP); 2004.

11. Joshi SK. Human trafficking in Nepal: a rising concern for all. Kathmandu Univ Med J. 2010;8(29):3-4.

12. Kaufman MR, Crawford M. Research and activism review: sex trafficking in Nepal: a review of intervention and prevention programs. Violence Against Women. 2011;17(5):651-665.
13. Tsutsumi A, Izutsu T, Poudyal AK, Kato S, Marui E. Mental health of female survivors of human trafficking in Nepal. Soc Sci Med. 2008;66(8): 1841-1847.

14. Chung RJ, English A. Commercial sexual exploitation and sex trafficking of adolescents. Curr Opin Pediatr. 2015;27(4):427-433.

15. Hudlow J. Fighting human trafficking through transit monitoring: a datadriven model developed in Nepal. J Hum Traffick. 2015;1(4):275-295.

16. Roberts MJ, Reich MR. Ethical analysis in public health. Lancet. 2002;359(9311):1055-1059.

17. Gostin LO, editor. Public Health Law and Ethics: A Reader. 2nd ed. California: Univeristy of California Press; 2010.

18. Tannahill A. Beyond evidence - to ethics: a decision-making framework for health promotion, public health and health improvement. Health Promot Int. 2008;23(4):380-390.

19. Public Health: Ethical Issues. London: Nuffield Council in Bioethics; 2007.

20. Nepal Law Commission [webpage on the Internet]. Human trafficking and transportation (control) act, 2007. Available from: http://www. lawcommission.gov.np/en/? s=\%09Human+Trafficking+and+Transp ortation $+\% 28$ Control $\% 29+$ Act $\% 2 \mathrm{C}+2064+\% 282007 \% 29$. Accessed December 27, 2015.

21. Holland S. Public Health Ethics. Hoboken, NJ, USA: John Wiley \& Sons; 2015.

22. Sanghera J, Kapur R. Trafficking in Nepal: Policy Analysis: an Assessment of Laws and Policies for the Prevention and Control of Trafficking in Nepal. Kathmandu, Nepal: Asia Foundation; 2000.

23. Shrestha R, Karki P, Suwal A, Copenhaver M. Sex trafficking related knowledge, awareness, and attitudes among adolescent female students in Nepal: a cross-sectional study. PLoS One. 2015;10(7):e0133508.

24. Coca K. Global Ethics Network [Internet] 2013. [cited 2015]. Available from: http://www.globalethicsnetwork.org/profiles/blogs/is-regulationthe-solution-to-sex-trafficking. Accessed December 28, 2015.

25 . Todres J. The importance of realizing 'other rights' to prevent sex trafficking. Cardozo J L Gender. 2006;12:885-907.

26. Annual Report 2014. Kathmandu, Nepal: Maiti Nepal; 2014.

27. United Nations. Human Rights and Human Trafficking. New York: United Nations Human Rights Office of the High Commissioner; 2014.

28. Dhital S, Aro A, Sapkota K. Health Impacts and research ethics in femaletrafficking. J Nepal Health Res Counc. 2011;9(1):89-91.

29. UN. Guide to Ethics and Human Rights in Counter-Trafficking. Ethical \& Human Rights in Counter-Trafficking. Bagkok, Thailand: United Nations Inter-Agency Project on Human Trafficking; 2008.

30. Harrison DL. Victims of Human Trafficking or Victims of Research. Rukopis dizertační práce Místo neznámé: University of East Anglia; 2006.

31. Christie T, Groarke L, Sweet W. Virtue ethics as an alternative to deontological and consequential reasoning in the harm reduction debate. Int J Drug Policy. 2008;19(1):52-58.
Medicolegal and Bioethics

\section{Publish your work in this journal}

Medicolegal and Bioethics is an international, peer-reviewed, open access journal exploring the application of law to medical and drug research and practice and the related ethical and moral considerations. The journal is characterized by the rapid reporting of reviews, case reports, guidelines and consensus statements, original research and surveys. The manuscript management system is completely online and includes a very quick and fair peer-review system. Visit http://www.dovepress.com/testimonials.php to read real quotes from published authors. 